\title{
Penggunaan Prinsip-Prinsip Exciting Classrooms dalam Meningkatkan Minat Belajar dan Kesadaran Berperilaku Baik Peserta Didik
}

\begin{abstract}
Akhmad Sulaiman
STAI DR. KHEZ. Muttaqien Purwakarta, Indonesia

cita.creative@gmail.com

DOI: https://doi.org/10.52593/pdg.01.1.03

Naskah diterima: 7 Maret 2020, direvisi: 5 April 2020, disetujui: 20 Juni 2020

Abstraksi

Dewasa ini, tidak ada istilah berhenti untuk mambahas masalah pendidikan. Pendidikan dapat dikaji dari berbagai perspektif. Di dalam ruang kelas, guru memegang peranan penting. Efektivitas tujuan pembelajaran bergantung pada guru. Namun, banyak fakta, yang menunjukkan bahwa hal itu tidak terjadi. Hal itulah saat pencipataan kelas yang menarik diperlukan. Kelas yang menarik mengandung arti, pembelajaran yang menginspirasi, menyenangkan dan menantang seperti yang telah dilaksanakan pada pembelajaran Akidah Akhlak di MAN Purwakarta.
\end{abstract}

Kata Kunci : Pembelajaran, Menyenangkan, Kelas, Inspiratif

\section{A. Pendahuluan}

Dalam hidup dan kehidupan manusia, pendidikan menempati posisi yang sangat strategis. Mengingat, dengan pendidikan, seorang manusia dapat menjadi manusia dewasa yang berkembang potensinya. Hal ini sejalan dengan apa yang disampaikan oleh Ahmad Tafsir, pendidikan ialah usaha meningkatkan diri dalam segala aspeknya $(2011 ; 5)$.

Dalam konteks individu, pendidikan dipandang sebagai upaya meningkatkan potensi yang dimiliki seseorang dalam segala potensinya. Dalam konteks sosial, pendidikan dapat dipandang sebagai upaya untuk meningkatkan daya saing dan kualitas suatu kelompok atau bahkan bangsa dan negara. Ini terjadi, ketika setiap individuindividu dalam suatu kelompok memiliki kualitas diri yang baik, maka akan membentuk suatu kumpulan kolektif yang berkualtas yang pada akhirnya membentuk suatu komunitas yang positif.

Dalam prosesnya, pendidikan yang dilakukan di dalam kelas, memiliki sejumlah komponen. Komponen itu ialah tujuan, isi, metode, evaluasi, media, serta lingkungan. Menyoal tujuan pendidikan, dalam perspektif Islam, tujuan pendidikan ialah mengarahkan peserta didik untuk siap menjadi khalifah di muka bumi serta menjadi hamba Allah. Oleh karenanya, komponen lainnya, mengarah pada tujuan tersebut. Dalam konteks pemenuhan tujuan, dalam implementasi kurikulum 2013, orientasi pembelajaran merujuk pada pencapaian kompetensi yang dimiliki peserta didik. Kompetensi dimaksud 
terdiri dari aspek sikap, pengetahuan, dan keterampilan. Untuk mewujudkan itu, perlu adanya kesadaran serta kompetensi pendidik untuk mewujudkannya.

Pendidik yang dapat mewujudkannya dipandang sebagai pendidik yang efektif. Pendidik yang efektif tentu diwujudkan melalui proses yang tidak sederhana, mulai dari pembentukan personality, kemampuan delivery, penguasaan body of knowledge. Ia pun harus konsisten dalam menjalaninya. Pendidik yang baik dapat mewujudkan efektivitas pembelajaran. Efektivitas pembelajaran sendiri bergantung pada beberapa hal, diantaranya ialah cara mengajar pendidik, informasi yang disampaikan, dan respon peserta didik.

Selain aspek efektivitas hasil yang dibuktikan dalam ketercapaian tujuan, proses pembelajaran pun memegang peranan yang penting. Dalam proses pembelajaran yang baik, akan menciptakan dorongan dengan sendirinya pada peserta didik untuk mau mengingat, mau memahami, memiliki kesadaran sikap positif serta mau mengamalkan pengetahuan yang dipelajarinya. Namun, bila dalam prosesnya pendidik tidak mampu menggairahkan dalam proses pembelajaran, maka peserta didik akan sulit untuk mendoron dirinya sendirinya untuk mau mengingat, mau memahami, untuk memiliki kesadaran sikap positif serta untuk mengamalkan pengetahuan yang dipelajarinya. Pendidik, dalam menjalani tugas mulianya mendidik, dihadapkan pada situasi yang tidak mudah. Selalu ada banyak tantangan terjadi. Saat di kelas misalnya, seringkali misalnya mendapati peserta didik yang tidak bersemangat dalam belajar, tidak antusias, tidak fokus, mudah lupa, malas mengerjakan tugas, serta sejumlah kondisi negatif lainnya yang terjadi. Kondisi tersebut pada akhirnya akan menjadikan peserta didik tidak mampu dalam menerima dan meresap informasi yang diberikan pendidik.

Pembelajaran akidah akhlak, pada aspek materi akhlak, merupakan pembelajaran yang orientasinya tidak hanya sekedar pengetahuan semata, namun harus mampu membuat peserta didik memiliki kesadaran melakukan akhlak yang baik dan meninggalkan akhlak yang tidak baik. Dengan dimilikinya kesadaran, ia akan secara terbiasa melakukan hal baik dan meninggalkan hal buruk.

Di sisi lain, apa yang diterima peserta didik di sekolah (madrasah), bukan hanya pembelajaran akidah akhlak, tapi juga lainnya, belum lagi bila dikaitkan dalam konteks lingkungan yang dijalani peserta didik, peserta didik dipengaruhi olah aspek lain yang kompleks dalam kehidupannya. Oleh karena itu dibutuhkan inovasi yang dilakukan pendidik agar peserta didik memiliki kesadaran untuk melaksanakan perilaku yang baik dan meninggalkan perilaku yang buruk.

Untuk mencipatakan kondisi itu, diperlukan peran pendidik yang dapat mewujudkannya. Keberadaaan pendidik sangat penting dalam mendesain proses pembelajaran dan melaksanakan. Ada banyak pendapat yang menyatakan bahwa manusia akan dengan mudah menerima dan menyerap informasi hanya ketika kedaannya merasa enjoy, aman, serta bahagia. Pandangan itu memunculkan gagasan tentang perlunya penciptaan kelas yang exciting. Kelas yang exciting dipahami sebagai kelas yang membuat siswa merasa tertarik untuk belajar,di dalamnya terdapat situasi yang enjoyful, challenging, serta inspiring. 
Penelitian ini bertujuan untuk mengetahui : 1) perencanaan pembelajaran dengan penggunaan prinsip pembelajaran exciting classroom; 2) pelaksanaan pembelajaran dengan penggunaan prinsip pembelajaran exciting classroom; dan 3) efektivitas pembelajaran dengan penggunaan prinsip pembelajaran exciting classroom. Adapun mnfaat penulisan ini bertujuan untuk pengembangan keilmuan, memperkaya khasanah keilmuan dalam bidak praktik pendidikan terutama pada aspek impelementasi pembelajaran, mengembangkan proses pembelajaran yang efektif dalam membangun kesadaran berbuat baik, dan membantu menciptakan kualias pendidikan pada aspek proses pembelajaran serta peserta didik agar memiliki ketertaikan dalam belajar sehingga menyadari pentingnya belajar, pada akhirnya ia akan mudah faham, mau dan terampil dalam mengamalkan kebaikan yang didapatd alam proses pembelajaran.

\section{B. Teori / Konsep}

\section{Exciting Classrooms}

Secara bahasa exciting classrooms berasal dari kata exciting dan classrooms. Exciting artinya menarik, sementara classroom artinya ruang kelas. Secara bahasa artinya, kelas yang dapat menarik, dalam hal ini memiliki makna, ruang kelas (pembelajaran) yang membuat peserta didik mau belajar.

Secara istilah, dalam pandangan Frank Thoms berikut uraian mengenai konsep exciting classrooms (Thoms, 2015, hal. xiv - xv).

Exciting Classrooms points out that teacer have an opportunity a significant impact on students and their families. They can begin by relinqusing strict classrooms control from the front. When they let go of this delivery mode, they are able to interact better with students. They invite students to become more receptive. In deciding to meet the halfaway-perhaps more than halfway- they make learning more possible.

They can shift from delivering knowledge and skill and concentrate instead on what student are learninng in their classrooms. The intention of teaching, after all, is to cause learning. It's not what teacher teach-essential as it may seen-but what students learn that counts. When teachers make this sift, they mentally leave the front of the room to teach alongside students. They interact with them and enrich their thinking, creativity, assesment and communication. The

create exciting and engaged classrooms. When teachers commit to this shift, students will learn ho to teach themselves.

Dari uraian di atas, bahwa exciting classrooms adalah kelas yang membuat peserta didik mau belajar sendiri. Perspektif yang digunakan bukanlah guru - dalam arti menyampaikan pengetahuan-, tetapi dalam perspektif peserta didik- dalam arti apa yang dipelajari peserta didik-. Hal yang harus dilakukan pendidik ialah mengubah pandangan dari pendidik sebagai pusat pengetahuan yang menyampaikan 'di depan kelas', ke orientasi pembelajaran "di samping” peserta didik. Sehingga terjadi interaksi antara peserta didik dan pendidik, mengembangkan pemikiran peserta didik, kreativitas, pengujian serta komunikasi. 
Pandangan itu memunculkan gagasan tentang perlunya penciptaan kelas yang exciting. Kelas yang exciting dipahami sebagai kelas yang membuat siswa merasa tertarik untuk belajar, di dalamnya terdapat situasi yang enjoyful, challenging, serta inspiring. Kelas yang enjoyful adalah kelas yang membuat peserta didik merasa nyaman untuk belajar.

Kelas yang challanging adalah kelas yang menantang, membuat siswa termotivasi. Sementara kelas yang inspiring adalah kelas yang memberikan inspirasi, sehingga dari kelas seperti ini akan memberikan dampak perubahan pada diri peserta didik untuk mengetahui, untuk berbuat, serta bersikap yang baik sesuai dengan tujuan pembelajaran. Kelas enjoyful dibentuk melalui beberapa upaya diantaranya, 1) melakukan ice breaking, misalnya melalui yel-yel atau games 2) penggunaan media yang menarik, 3) penggunaan instrument music, 3) bermain, 4) variasikan metode terutama yang berbasis emosi dan psikologi.

Kelas challanging dibentuk melalui beberapa upaya, 1) pemberian rewards bagi yang memiliki upaya dan kompetensi lebih, 2) pemberian point, 3) menggunakan media online untuk penilaian harian yang nilainya di-share secara terbuka. Kelas inspiring dibentuk melalui beberapa tahap, diantaranya : 1) ingatkan tujuan, 2) pemberian motivasi, 3) menggunakan media dan teknik yang menyentuh psikologi.(Manpan Drajat, 2015; Suci Nurpratiwi, Muhamad Ridwan Effendi, 2021)

\section{Minat Belajar}

Secara bahasa minat berasal dari Bahasa Inggris interest yang berarti kesukaan, perhatian (kecenderungan hati pada sesuatu), keinginan. Menurut Muhibbin Syah (2000, hal. 136) merupakan kecenderungan dan kegairahan yang tinggi atau keinginan yang besar terhadap sesuatu. Sementara menurut Slameto (1995, hal. 180) minat adalah suatu rasa lebih suka dan rasa keterikatan pada suatu hal atau aktivitas, tanpa ada yang menyuruh. Dari pendapat yang ada, minat dapat difahami sebagai kesukaan, ketertarikan, perhatian, keinginan lebih yang dimiliki seseorang terhadap sesuatu tanpa ada dorongan. Ini mengandung bahwa bila seseorang memiliki minat yang tinggi, ia akan merasa tertarik dan memperhatikan sesuatu.

Peserta didik yang memiliki minat menunjukkkan beberapa hal berikut (Slameto, 1995, hal. 57):

1) Memiliki kecenderungan yang tetap untuk memperhatikan dan mengenang sesuatu yang dipelajari secara terus-menerus.

2) Ada rasa suka dan senang terhadap sesuatu yang diminatinya.

3) Memperoleh sesuatu kebanggaan dan kepuasan pada suatu yang diminati.

4) Lebih menyukai hal yang lebih menjadi minatnya daripada hal yang lainnya

5) Dimanifestasikan melalui partisipasi pada aktivitas dan kegiatan.

Dalam konteks penulisan karya inovasi ini, minat belajar tersebut dimaknai sebagai berikut:

a) Perasaan Senang 
Bila peserta didik memiliki perasaan senang terhadap mata pelajaran maka ia tidak akan ada merasa terpaksa untuk belajar. Contohnya, mengerjakan tugas dengan tepat waktu, mengikuti pelajaran dengan penuh rasa gembira, menanti kehadiran mata pelajaran.

\section{b) Ketertarikan}

Ketertarikan ini merupakan perasaan suka terhadap sesuatu, sehingga melahirkan antusias pada sesuatu. Contoh: antusias dalam mengikuti pelajaran, tidak menunda tugas dari guru.

\section{c) Keterlibatan Siswa}

Ketertarikan seseorang pada sesuatu mengakibatkan orang tersebut senang dan tertarik untuk melakukan atau mengerjakan secara terlibat pada kegiatan dari obyek tersebut. Contoh: aktif dalam diskusi, aktif bertanya, dan aktif menjawab pertanyaan dari guru, aktif berkerja sama.

\section{d) Perhatian Siswa}

Perhatian merupakan perhatian siswa pada objek tertentu serta memberikan fokus dan konsenterasi pada objek yang disukai. Peserta didik yang memiliki minat pada obyek tertentu maka dengan sendirinya akan memperhatikan obyek tersebut

\section{Kesadaran Berperilaku Baik}

Secara bahasa, dalam Kamus Besar Bahasa Indonesia, kesadaran ialah keinsafan keadaan mengerti, hal yang dirasakan atau dialami oleh seseorang. Secara istilah dalam pandangan penulis, kesadaran adalah kondisi seseorang saat ia mengetahui atau mengerti dengan jelas apa yang ada dalam dalam stimuli inderawi dan fikirannya. Fikiran dalam konteks ini dipahami sebagai ingatan, hasil berpikir, akal, gagasan ataupun maksud atau niat.

Dalam konteks penelitian ini, menurut pandangan penulis yang dimaksud dengan kesadaran berperilaku baik ialah keadaan seseorang dimana ia mengetahui arti penting, memahami konsepsinya, menerima sampai pada merancang mekanisme pola untuk mengamalkan suatu perbuatan yang baik.

Menurut Soekanto (2002) menyatakan bahwa terdapat empat ciri kesadaran, ciri ini menjadi suatu tahapan bagi tahapan berikutnya dan menunjuk pada tingkat kesadaran tertentu, mulai dari yang terendah sampai yang tinggi, antara lain: pengetahuan, pemahaman, sikap, dan pola perilaku (tindakan).

Dalam konteks penelitian ini, menurut pandangan penulis yang dimaksud dengan kesadaran berperilaku baik ialah keadaan seseorang dimana ia mengetahui arti penting, memahami konsepsinya, menerima sampai pada merancang mekanisme pola untuk mengamalkan suatu perbuatan yang baik. 
Dalam studi ini yang kesadaran berperilaku baik dilihat dalam bentuk beberapa hal menerima aspek sikap yang dibiasakan sesuai materi, berkeinginan untuk mengamalkannya, dan mengamalkannya dalam kehidupan sehari-hari.

\section{Metode Penelitian}

Penelitian ini menggunakan studi kualitatif deskriptif, yakni menggambarkan proses pembelajaran yang dilakukan dengan menggunakan exciting classrooms pada pembelajaran di MAN Purwakarta. Penelitian berawal dari adanya keresahan peniliti yang menemukan kondisi di mana pembelajaran tidak berlangsung efektif. Proses berikutnya adalah menyusun teoritiasi, perencanaan pembelajaran, dan menyusun instrumen penelitian.

Instrumen pengukuran minat belajar menggunakan instrumen rubrik minat belajar sebagaiamana format berikut.

\begin{tabular}{|c|c|c|c|c|c|c|c|}
\hline \multirow{2}{*}{ No } & Nama Peserta & \multicolumn{4}{|c|}{ Aspek Pengukuran Minat Belajar } & \multirow{2}{*}{$\begin{array}{c}\text { Total } \\
\text { Didik }\end{array}$} & \multirow{2}{*}{ Ketegori } \\
\cline { 3 - 6 } & & & SB & KB & LB & PB & \\
\hline 1 & & & & & & & \\
\hline 2 & & & & & & & \\
\hline 3 & & & & & & \\
\hline
\end{tabular}

\section{Keterangan}

Aspek minat belajar dilihat dalam bentuk:

1. Menunjukkan perasaan senang belajar

2. Menunjukkan perasaan ketertarikan dalam belajar

3. Menunjukkan keterlibatan peserta didik dalam aktivitas belajar

4. Menunjukkan perhatian peserta didik untuk belajar

Instrumen pengukuran kesadaran berperilaku baik menggunakan instrumen angket dengan format sebagaiman berikut.

\section{Lembar Angket}

Nama Peserta Didik :

Kelas

\section{Petunjuk}

Berilah tanda ceklist pada salah aspek sesuau keaadan sendiri sesuai pernyataan yang diminta!

1. Terdapat beberapa nilai positif dalam asmaul husna, tingkatan penerimaan anda mengenai nila-nilai positif dimaksu

\begin{tabular}{|c|c|c|c|c|}
\hline $\begin{array}{c}\text { Sangat } \\
\text { Menerima }\end{array}$ & Menerima & Biasa Saja & Menolak & $\begin{array}{c}\text { Sangat } \\
\text { Menolak }\end{array}$ \\
\hline & & & & \\
\hline
\end{tabular}


2. Pada saat yang memungkinkan, tingkatan keinginan Anda untuk mengamalkan sikap-sikap sesuai asmaul husna yang telah dipelari

\begin{tabular}{|c|c|c|c|c|}
\hline Sangat Ingin & Ingin & Biasa Saja & Tidak Mau & $\begin{array}{c}\text { Sangat } \\
\text { Tidak Mau }\end{array}$ \\
\hline & & & & \\
\hline
\end{tabular}

3. Pada saat yang memungkinkan, tingkatan pengamalan Anda untuk mengamalkan sikap-sikap sesuai asmaul husna yang telah dipelari

\begin{tabular}{|l|l|l|l|l|}
\hline Membiasakan & Sering & Biasa Saja & Jarang & Tidak Pernah \\
\hline & & & & \\
\hline
\end{tabular}

Adapun materi pembelajaran dilaksanakan pada materi asmaul husna kelas 12, yakni pada aspek definisi, dalil yang berkaitan, urgensi serta cara meneladaninya.

Sementara metode pembelajaran yang digunakan adalah menggunakan Gallery Walk dipadukan dengan pendekatan NLP yakni Self Perseptual Position dan New Behavior Generation. Gallery Walk (pameran berjalan) merupakan sebuah strategi pembelajaran yang memperkenalkan pameran (hasil karya peserta didik) ke kelompok lain dalam kelas Self Perseptual Position adalah sebuah teknik dalam NLP untuk memperluas sudah pandang dan memperluas persepsi dalam komunikasi. Posisi persepsi, sendiri artinya berpindah posisi utuk merubah posisi disi sendiri untuk mendapatkan pemahaman baru. Dan arah yang digunakannya ialah new behaviour generation (merubah perilaku baru). (referensi training)

\section{Pemikiran Pendidikan Islam HOS Tjokroaminoto}

\section{Minat Belajar}

Dari hasil pengukuran yang dilakukan, berada pada kategori sangat baik sebanyak 20 orang dari 34 peserta didik (59\%), 10 orang dari 34 peserta didik (29\%) artinya pada kategori baik, dan 4 orang dari 34 peserta didik yang berada pada kategori cukup (12\%). Sementara itu, tidak ada peserta didik yang berada pada kategori kurang. Hal ini menunjukkan inovasi pembelajaran yang penulis lakukan dapat meningkatkan minat belajar peserta didik. Perolehan itu bila digambarkan akan tampak pada grafik berikut.

\section{Grafik 1}

\section{Perolehan Minat Belajar}




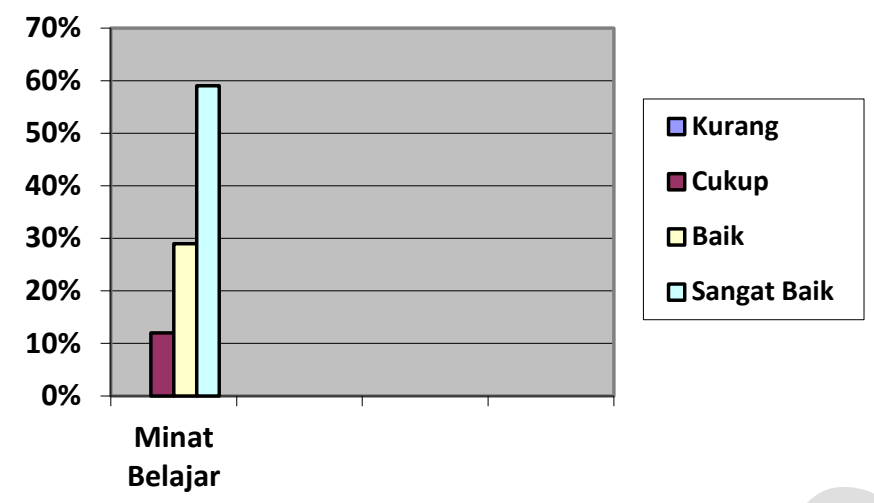

Hasil itu menunjukkan bahwa minat belajar peserta didik memiliki rata-rata kelas pada kategori "sangat baik". Ini menunjukkan bahwa penggunaan prinsip exciting classrooms dapat meningkatkan minat belajar.

\section{Kesadaran berperilaku baik}

Dari hasil pengukuran yang dilakukan, terdapat 26 orang dari 34 peserta didik orang yang berada pada ketgori sangat baik, dengan prosentasi $76 \%$; terdapat orang dari 34 peserta didik pada kategori baik, dengan prosesntase 15\%, dan 3 orang dari 34 peserta didik pada kategori cukup, dengan prosentasi 9\%. Apabila digambarkan dalam grafik, akan tampak pada grafik berikut.

\section{Grafik 2}

\section{Kesadaran Berperilaku Baik}

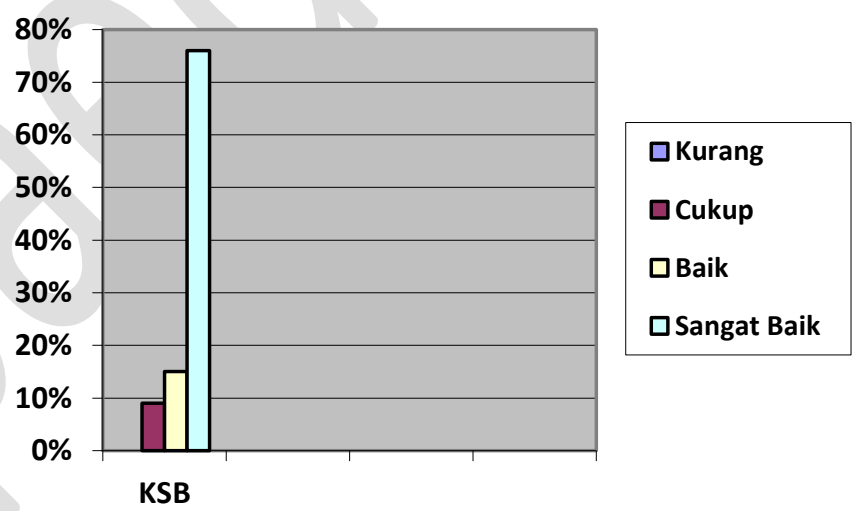

Hal ini dapat disimpulkan bahwa pelaksanaan inovasi pembelajaran berhasil dilaksanakan. Di samping hal-hal di atas, peserta didik juga menunjukkan perubahan sikap yang drastis, serta berdasarkan penelusuran pengisian form pengetahuan pada jenis meta kognitif, peserta didik berantusias untuk mengamalkan perilaku yang digambarkan dalam asmaul husna.

Apabila kedunya digambarkan, akan tampak pada grafik berikut.

\section{Grafik 3. Minat Belajar dan Kesadaran Berperilaku Baik}




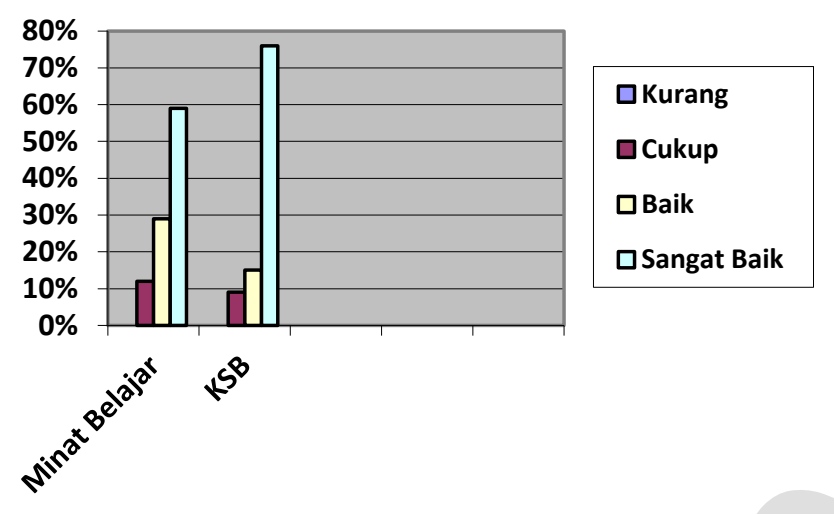

Dari hasil keduanya, menunjukkan hasil yang menggambarkan keadaan sangat baik. Minta belajar, dengan rata-rata sebesar 59\% dan kesadaran berperilaku dengan rata-rata $76 \%$. Berdasarkan analisa penulis, hal ini terjadi baru pada awalnya, mengingat sebelumnya, belum pernah menjalankan semua prinsip exciting classrooms secara utuh. Faktor lain yang menjadi daya tarik adalah penggunaan perangkat audio yang maksimal.

\section{E. Simpulan}

Berdasarkan penulisan di atas, berikut beberapa hal yang dapat disimpulkan :

1. Perencanaan pembelajaran dengan penggunaan prinsip pembelajaran exciting classroom adalah dengan menerapkan prinsip exciting classrooms, yakni enjoyful, challenging dan inspiring.

2. Pelaksanaan pembelajaran dengan penggunaan prinsip pembelajaran exciting classroom; dilakukan dalam 2 pertemuan pada pembelajaran akidah akhlak. Pelaksanaan prinsip exciting dibreakdown pada beberapa pentahapan.

3. Efektivitas pembelajaran dengan penggunaan prinsip pembelajaran exciting classroom, berdasarkan instrumen yang digunakan pada aspek yang diukur, terlihat menunjukkan hasil efektif. 


\section{Daftar Pustaka}

Manpan Drajat, M. R. E. (2015). Etika Ptrofesi Guru. Alfabeta.

Effendi, M. Ridwan dan Manpan Drajat. Etika Profesi Guru. Cet. I: Bandung; Alfabeta, 2014.

Suci Nurpratiwi, Muhamad Ridwan Effendi, A. (2021). Improving Religious Literacy

Through Islamic Religious Education Course Based On The Flipped Classroom.

Istawa, 6(1), 16-29. https://doi.org/http://dx.doi.org/10.24269/ijpi.v6i1.3107

javascript:void(0)

Sanjaya, W. (2006). Pembelajaran dalam Implementasi Kurikulum Berbasis Kompetensi. Jakarta: Prenada Media.

Sanjaya, W. (2008). Strategi Pembelajaran: Berorientasi Standar Proses Pendidikan. Jakarta: Prenada Media.

Slameto. (1995). Belajar dan Faktor-faktor yang Mempengaruhinya. Jakarta: Rineka Cipta.

Soekanto, S. (2002). Kesadaran Hukum dan Kepatuhan Hukum. Jakarta: Rajawali .

Syah, M. (2000). Psikologi Pendidikan dengan Pendekatan Baru. Bandung: Remaja Rosda Karya.

Tafsir, A. (2011). Metodologi Pengajaran Agama Islam. Bandung: Remaja Rosda Karya. Thoms, F. (2015). Exciting Classrooms: practical information to ensure student success. London: Rowman \& Littelfield. 